\title{
Dural ectasia in Marfan syndrome
}

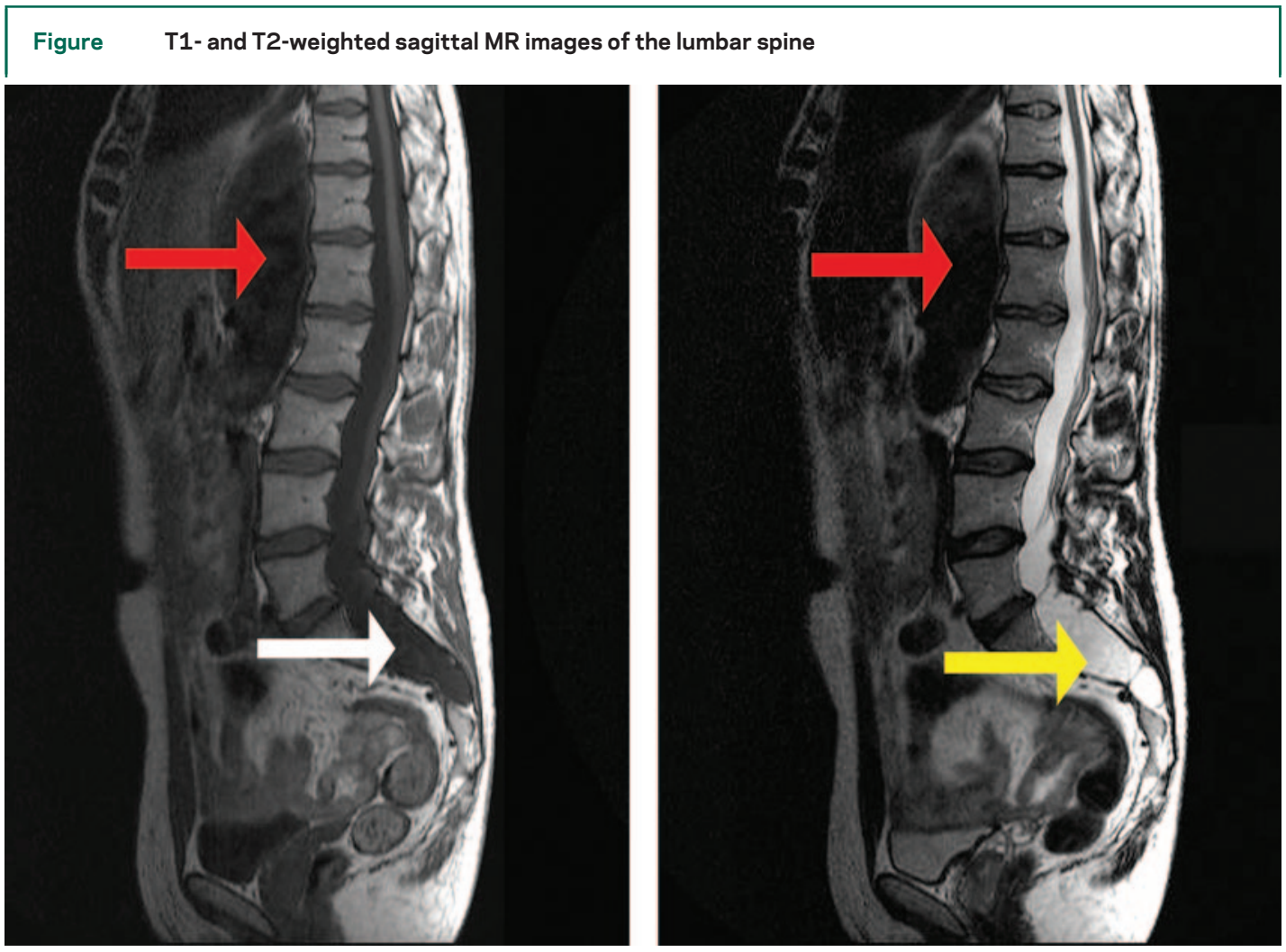

T1- and T2-weighted sagittal MR images of the lumbar spine reveal enlargement of the thecal sac (yellow arrow) with mild scalloping of the lumbar vertebral bodies and marked focal thinning of the sacrum (white arrow). An enlarged flow void anterior to the spine (red arrow) is related to dilation of the descending aorta.

A 29-year-old man was admitted to the hospital with intermittent recurrent episodes of back pain confined to the sacral area. During the course of his workup an MR examination was performed (figure).

Marfan syndrome ${ }^{1}$ is an inherited multisystemic connective tissue disorder diagnosed by a combination of major and minor diagnostic criteria in each body system.

Dural ectasia ${ }^{2}$ is a dilation of the dural sac and it is considered one of the major diagnostic criteria of Marfan syndrome; aortic dilation is considered one of the minor diagnostic criteria in the cardiovascular system.

\section{Sánchez, MD, L. Concepción, MD, PhD, J.J. Cortés, MD, and C. Pack, MD, Alicante, Spain}

Disclosure: The authors report no disclosures.

Address correspondence and reprint requests to Dr. I. Sánchez, Servicio Radiodiagnóstico, Hospital Universitario Alicante, Alicante, Spain; issapi@latinmail.com

1. Judge D, Dietz H. Marfan's syndrome. Lancet 2005; 366.

2. Habermann C, Weiss F, Schoder V, Cramer M. MR evaluation of dural ectasia in Marfan syndrome: reassessment of the established criteria in children, adolescents, and young adults. Radiology 2005;234:535-541. 


\section{Neurology}

Dural ectasia in Marfan syndrome

I. Sánchez, L. Concepción, J. J. Cortés, et al. Neurology 2008;71;1378

DOI 10.1212/01.wnl.0000327702.26686.7b

This information is current as of October 20, 2008

\section{Updated Information \&} Services

References

Citations

Subspecialty Collections

Permissions \& Licensing

Reprints including high resolution figures, can be found at: http://n.neurology.org/content/71/17/1378.full

This article cites 1 articles, 0 of which you can access for free at: http://n.neurology.org/content/71/17/1378.full\#ref-list-1

This article has been cited by 1 HighWire-hosted articles: http://n.neurology.org/content/71/17/1378.full\#\#otherarticles

This article, along with others on similar topics, appears in the following collection(s):

\section{All Cerebrovascular disease/Stroke}

http://n.neurology.org/cgi/collection/all_cerebrovascular_disease_strok e

All Medical/Systemic disease

http://n.neurology.org/cgi/collection/all_medical_systemic_disease All Spinal Cord

http://n.neurology.org/cgi/collection/all_spinal_cord

MRI

http://n.neurology.org/cgi/collection/mri

Information about reproducing this article in parts (figures,tables) or in its entirety can be found online at:

http://www.neurology.org/about/about_the_journal\#permissions

Information about ordering reprints can be found online:

http://n.neurology.org/subscribers/advertise

Neurology ${ }^{\circledR}$ is the official journal of the American Academy of Neurology. Published continuously since 1951, it is now a weekly with 48 issues per year. Copyright . All rights reserved. Print ISSN: 0028-3878. Online ISSN: 1526-632X.

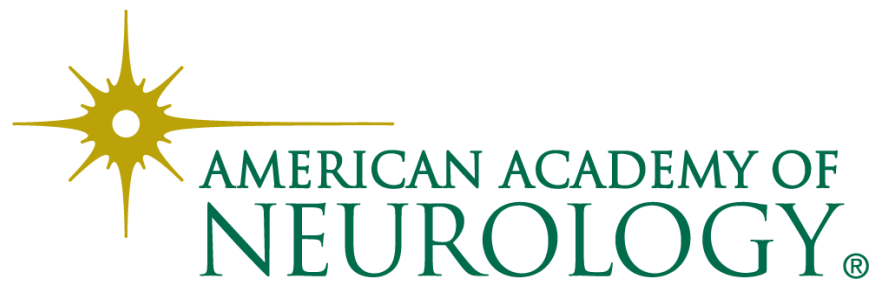

